\title{
RELATIONSHIP BETWEEN UTILITARIAN AND HEDONIC CONSUMER BEHAVIOR AND SOCIALLY RESPONSIBLE CONSUMPTION
}

\author{
Karina Adomaviciute \\ Vilnius University, Lithuania

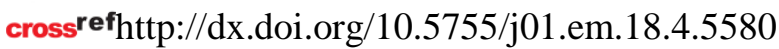

\begin{abstract}
Consumption processes in modern societies are constantly gaining in importance. Noticing the growing significance of consumption, the idea of some consumer responsibility for the currently observed crises gains relevance. Despite the increasing number of publications on the subject of socially responsible consumption, however ethical side of socially responsible consumption is not receiving enough attention, the majority of publications are focused on environmental consumption. In addition, little attention is paid to analyze ethical side of socially responsible consumption from the individual side. Measurement of the relationship between the utilitarian and hedonic consumer behavior and socially responsible consumption may contribute to the knowledge of new characteristics, describing the socially responsible consumer. The paper suggest theoretical model, which helps to measure the relationship between utilitarian and hedonic consumer behavior and ethical side of socially responsible consumption. Utilitarian consumer behavior is measured with the constructs like monetary savings and convenience, as the hedonic behavior is described by using entertainment and exploration constructs. Performed literature analysis suggests, that hedonic consumer behavior has greater impact on socially responsible consumption than utilitarian consumer behavior.
\end{abstract}

The type of the article: Theoretical article.

Keywords: socially responsible consumption, hedonic behavior, utilitarian behavior.

JEL Classification: M31, M39.

\section{Introduction}

It is generally observed that people see themselves as consumers in more and more spheres of their live. The definition of consumption often means to consume, waste, squander or destroy (Francois-Lecompte, Roberts, 2006). Directly or indirectly, the consumption of goods and services causes many urgent social and environmental problems. A number of present environmental problems can be linked to consumer lifestyles. More sustainable lifestyles cannot be reached without marking changes in consumer behavior, attitudes and values. The performed research results showed that consumers are becoming more conscious to include ethical principles in their purchase decisions (Roberts, 1995, 1996). Price, quality, value and convenience appear to be the most important buying criteria for a large segment of consumers and products with an environmental or social appeal have an added advantage if they meet other competitive requirements. As consumers are one of the main stakeholders group in the market, it is essential for marketers seeking to tap into this market to understand the concerns of the consumers as well as how the latter translate into new forms of consumer's behavior (Binninger, Robert, 2008). Therefore the study of socially responsible consumption (SRC) became of critical importance.

Despite the increasing number of publications on the subject of socially responsible consumption, however ethical side of socially responsible consumption is not receiving enough attention, the majority of publications are focused on environmental consumption. Foreign researcher identified different scales to measure socially responsible consumption in a broad sense, but existing models are not fundamental. In addition, little attention is paid to analyse ethical side of socially responsible consumption from the individual side, i.e. what motives, values, emotions 
affect individuals to start consume ethically. Literature analysis on consumer behavior suggest, that consumer purchase goods and services and perform consumption behavior because of the two basic reasons: hedonic and utilitarian. Hence the analysis of the relationship between hedonic and utilitarian consumer behavior and ethical consumption is of crucial importance. The results of analysis will show, what better describes the ethical consumer behavior: emotions or rational thinking.

The following research methods are used in the article: the systematic and comparative analysis of scientific literature in the field of socially responsible consumption, utilitarian and hedonic consumer behavior. The purpose of this article is to establish theoretical model, which helps to measure the relationship between utilitarian and hedonic consumer behavior and ethical side of socially responsible consumption.

\section{Concept of ethical consumption as a part of SRC}

Theoretically, the concept of socially responsible consumption has changed over the years. Webster (1975) defined socially conscious consumer "as a consumer who takes into account the public consequences of his or her private consumption or who attempts to use his or her purchasing power to bring about social change" (p. 188). His definition stressed the idea, that socially conscious consumer have to be aware of social problems and active in the community and must believe in his or her power to make changes. Follows and Jobber (2000) indicated that socially responsible consumer evaluates the product use impact on society before he takes purchasing decision. This proposes that socially responsible consumption should reflect consumer values within the natural, environmental, social and economic aspects. Mohr et al. (2001) defined socially responsible consumer as a person basing his or her acquisition, usage and disposition of products on a desire to minimize or eliminate any harmful effects and maximize the long-run beneficial impact on society. Researchers divide socially responsible consumption in 2 main parts (see Figure 1): ethical and environmental consumption (responsibility) (Paek, Nelson, 2009; François-Lecompte, 2005).

The analysis of socially responsible consumption is based on both environmental and ethical consumption-dimensional assessment including consumers socio-demographic and characteristics of the values (Adams, Raisborough, 2010). Despite the increasing number of publications on the subject of socially responsible consumption however ethical side of socially responsible consumption is not receiving enough attention, the majority of publications are focused on environmental aspect of socially responsible consumption.

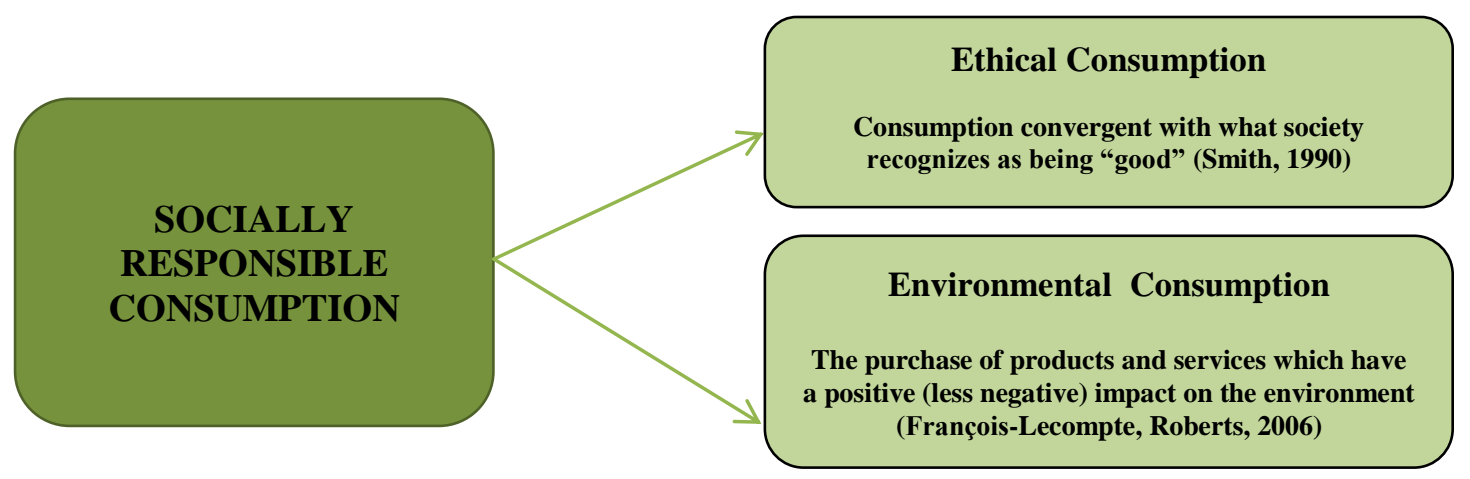

Figure 1. Concept of socially responsible consumption

Researchers have identified such key social issues related to ethical behavior: fair trade (DePelsmacker, Janssens, 2007; Nicholls, Opal, 2005), trade of organically grown and processed products (Tsakiridou et al., 2008), work processes in developing countries (Joergens, 2006; Dickson, 1999). A lof of researchers examined the sociodemographics of ethical consumer (Carrigan, Attalla, 2001; Vitell et al., 2001; Roberts, 1996). However only few research investigated consumer values and their influence on ethical behavior (Dickson, 1999; Roberts, 
1996; Fritzche, 1995). Moreover, comparatively little attention has been paid to the role that ethics plays in individual purchasing behavior (Nicholls \& Lee, 2006). Among the limited investigation on individual ethical decision-making, two famous theoretical approaches are Hunt and Vitell's general theory of marketing ethics (Hunt \& Vitell, 1986) and different models that are based on the behavioral theories of Ajzen and Fishbein (Chatzidakis et al., 2006).

Crane and Matten (2004) suggest that the main essence of the concept of ethical consumption is "the conscious and deliberate decision to make certain consumption choices due to personal moral beliefs and values". Ethical consumers are likely to look after the developing world and largely that producers should get fair wages and improved working conditions as well as concerns about animal well-being, pollution and waste (Shaw \& Clarke, 1998). Szmigin and Carrigan (2006) stressed, that ethical consumption is as large part of the active social process of consumption with its material and symbolic dimensions as any other form of consumption. This is the reason, why ethical consumption could not be seen (individually) in isolation, but should be accepted that ethical characteristics will be evaluated by consumers with others relevant to their choice decisions (Shaw \& Clarke, 1998).

\section{Hedonic versus utilitarian consumer behavior}

A behavior of the consumer is a result of attitudes, motives and values and may evidence into purchase and consumption behavior. Literature analysis on consumer behavior suggest that consumer purchase goods and services and perform consumption behavior because of the two basic reasons (Teller et al., 2008; Millan, Howard, 2007; Batra, Ahtola, 1990; Holbrook, Hirschman, 1982; Millar, Tesser, 1986):

- hedonic gratification (from sensory attributes);

- utilitarian reasons concerned (from functional and nonsensory attributes).

Both the utilitarian and hedonic aspects are bipolar by nature. Hedonic aspect includes unpleasant feelings as well as pleasant, as at the same time utilitarian aspect includes judgements about irrationality as well as rationality, functional and product-centric thinking (Rintamaki et al., 2006; Ahtola, 1985). Hedonic value is associated with satisfaction of the senses enlarged by experiences of pleasure, entertainment, fantasy and fun (Holbrook, Hirschman, 1982; Babin et al., 1994). Utilitarian value can be characterized as task-related needs fulfillment. Constructs like monetary savings and convenience contribute to utilitarian value, as hedonic value can be described by using entertainment and exploration constructs (Chandon et al., 2000; Turley, Milliman, 2000; Rintamaki et al., 2006). Monetary savings mitigate the pain of paying (Chandon et al., 2000). Convenience can be defined as a ratio of inputs to outputs, time and effort being the relevant inputs (Seiders et al., 2000; Rintamaki et al., 2006). Exploration provides hedonic value, when customer evaluate the excitement of product and (or) information search (Chandon et al., 2000, Rintamaki et al., 2006). Moreover, hedonic value realized through entertainment is a reaction to aesthetic features (Rintamaki et al., 2006).

The notion hedonism is traditionally associated with a negative connotation linked with instant gratification and egoistic, individualistic materialism and excessive selfish behavior (Gabriel \& Lang, 1995, cited in Szmigin et al., 2007). However, there are many and controversial opinions as to what it means to behave hedonic in today's society (Gabriel, Lang, 1995). Soper (2007, 2008) and Soper et al. (2009) also support this idea. They argue, that ethical consumption can, in itself, be a hedonistic pursuit. In this regard, hedonism is based on individual's motivation to strive for the 'good life'. The 'good life' refers to an individual's discontent with consumerism and materialism resulting in a tendency to choose alternative forms of consumption practices. Hence considering the term hedonism it is necessary to analyse two forms of hedonism: egoistic and ethical. Egoistic hedonism is based on the idea that the happiness or the pleasure of the individual is the ultimate good or moral standard (Sidgwick, 1981). Based of the above mentioned sentence, it can be concluded, that egoistic hedonist do not concern welfare of others. While ethical hedonists are concerned not only with their own well-being, but the welfare of others. The concept ethical 
hedonism relates to the purchase and consumption of ethical goods as a pleasurable act. Hedonism can be a legitimate dimension of ethical consumption if it is accepted that doing the 'right thing' may be associated with feelings of self -respect which in turn give to the person feelings of pleasure (Szmigin, Carrigan, 2006). Wertenbroch (2002) pointed out, that consumer preferences are often driven by the anticipated hedonic experience, so this may still be within parameters of moral dimensions and self-control. Consumers will even achieve hedonic benefits from manipulating the set of choices they face (Wertenbroch, 2002). So an ethical choice may be more appealing when made in the presence of less ethical choices (Szmigin, Carrigan, 2006).

The analysis of scientific literature suggests that hedonic consumption causes a sense of guilt (Kivetz, Simonson, 2002; Strahilevitz, Myers, 1998, Belk et al., 2003). Broadly guilt can be understood as a negative self-conscious emotion aroused when person's conducts is at variance with person's own standards (Baumeister et al., 1995). Guilt can occur during purchase, in usage situations and even during disposition of the products (Dahl et al., 2003). Generally guilt has been determined as moral emotion linked to the welfare of other people or of society as a whole (Eisenberg, 2000). Guilt is typically observed as involving concern for moral standards or harm done to others (Tangney, Dearing, 2002). In this respect, researchers have been suggesting importance of guilt emotion in ethically questionable consumer situations. Marks and Mayo (1991) remarked, that people may experience the sense of guilt when choosing unethical alternative. Considering guilt as an emotion, it suggested that consumers tend to eliminate their guilt by coping behavior (Dedeoglu, Kazancoglu, 2012).

Based on scientific literature review the author of this article states that both hedonic and utilitarian consumer behavior can be the antecedents of the ethical consumption. However, hedonic consumer bahavior is analysed in this context much more wider and may be assumed as having greater impact on ethical consumption than utilitarian consumer behavior.

\section{Theoretical model of relationship between utilitarian and hedonic consumer behavior and ethical consumption}

Foreign researcher identified different scales to measure socially responsible consumption in a broad sense, but existing models are not fundamental. In addition, little attention is paid to analyse ethical side of socially responsible consumption from the individual side, i.e. what motives affect individuals to start consume ethically. The author of this paper thinks that measurement of the relationship between utilitarian and hedonic consumer behavior and ethical consumption as a part of socially responsible consumption may contribute to the fulfilment of this gap. Having all these in mind and based on scientific literature review author of the article established a new theoretical model (see Figure 2).

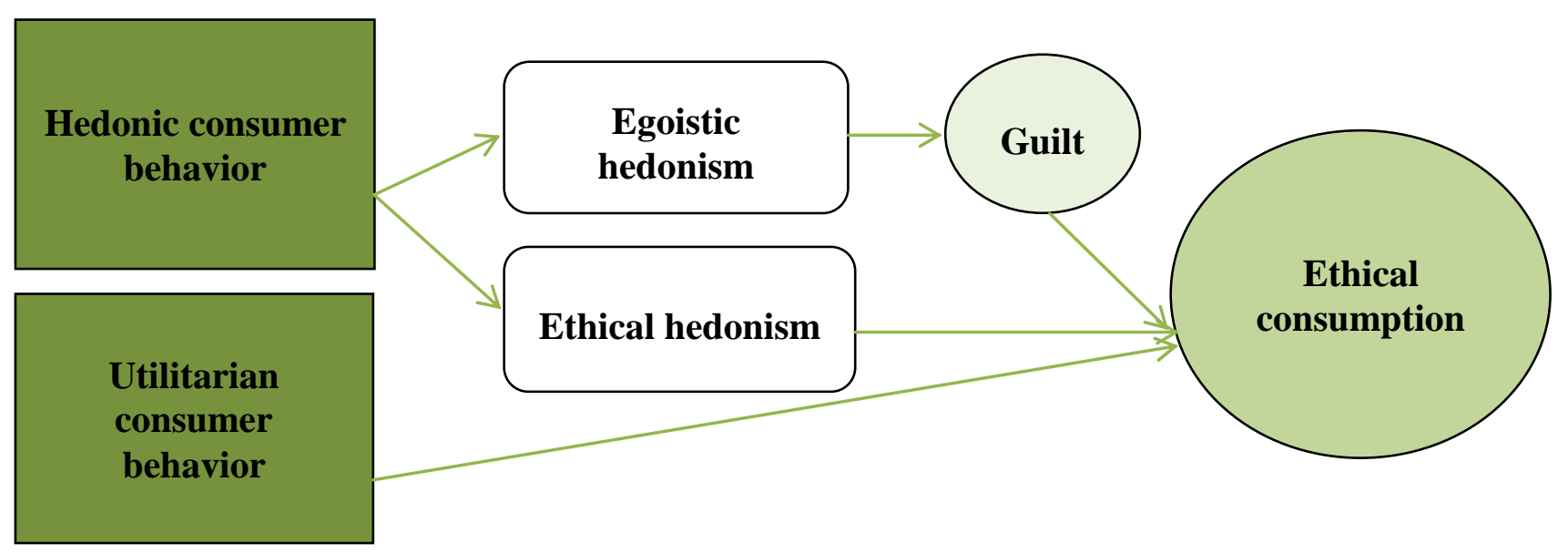

Figure 2. Theoretical model of relationship between utilitarian and hedonic consumer behavior and ethical consumption 
The model (see Figure 2) suggest that hedonic and utilitarian consumer behavior may be antecedents of ethical consumption. Author of the article assumes that egoistic hedonic consumer behavior may lead to the purchase of ethical products because of the impact of negative selfconscious emotion, called guilt. While ethical hedonic and utilitarian consumer behavior may have direct impact on ethical consumption.

\section{Discussion}

Despite the increasing number of publications on the subject of socially responsible consumption, however ethical side of socially responsible consumption is not receiving enough attention, especially in terms of motives affecting individuals to start consume ethically.

To sum up, the author of the article presents theoretical model, which helps to measure the relationship between utilitarian and hedonic consumer behavior and ethical consumption. Performed literature analysis and authors' stated assumptions suggest that hedonic consumer behavior may has greater impact on ethical side of socially responsible consumption than utilitarian consumer behavior. Author of the article assumes that egoistic hedonic consumer behavior may lead to the purchase of ethical products because of the impact of negative self-conscious emotion, called guilt, while at the same time ethical hedonic consumer behavior may have direct impact on ethical consumption.

Limitations of this paper are due to the fact that only theoretical considerations were presented, empirical research on analysed topic was not performed. Potential research on relationship between utilitarian and hedonic consumer behavior and ethical consumption would provide both marketing scientists and specialists with in-depth understanding of new characteristics describing the socially responsible (ethical) consumer.

\section{References}

Adams, M., Raisborough, J. (2010). Making a difference: ethical consumption and the everyday. The British Journal of Sociology, 61 (2), 256 - 274. doi:10.1111/j.1468-4446.2010.01312.x

Ahtola, O. T. (1985). Hedonic and Utilitarian Aspects of Consumer Behavior: an Attitudinal Perspective. Advances in Consumer Research, 12(1), 7-10. Retrieved from: http://www.acrwebsite.org/search/view-conference-proceedings.aspx? $\mathrm{Id}=6348$

Babin, B. J., Darden, W. R., Griffin, M. (1994). Work and/or fun: Measuring Hedonic and Utilitarian Shopping Value. Journal of Consumer Research, 20 (4), 644-656. doi:10.1086/209376

Batra, R., Ahtola O. T. (1990). Measuring the Hedonic and Utilitarian Sources of Consumer Attitudes. Marketing Letters, 2(2), 159-170. doi: 10.1007/BF00436035

Baumeister, R. F., Stillwell, A. M., Heatherton, T. F. (1995). Personal Narratives About Guilt: Role in Action Control and İnterpersonal Relationships. Basic and Applied Social Psychology, 17(1-2), 173-198. doi: 10.1080/01973533.1995.9646138

Belk, R. W., Ger, G., Askegaard, S. (2003). The Fire of Desire: A Multisided Inquiry into Consumer Passion. Journal of Consumer Research, 30(3), 326-351. doi:10.1086/378613

Binninger, A. S., Robert, I. (2008). Consommation et développement durable: vers une segmentation des sensibilités et des comportements. La Revue des Sciences de Gestion, Direction et Gestion, 1(229), 5159. ISBN: 9782916490113. http://dx.doi.org/10.1051/larsg:2008006

Carrigan, M., Attalla, A. (2001). The myth of the ethical consumer - do ethics matter in purchase behaviour. Journal of Consumer Marketing, 18(7), 560-577. doi: 10.1108/07363760110410263

Chandon, P., Wansink, B., Laurent, G. (2000). A Benefit Congruency Framework of Sales Promotion Effectiveness. Journal of Marketing, 64(4), 65-81. doi: http://dx.doi.org/10.1509/jmkg.64.4.65.18071

Chatzidakis, A., Hibbert, S., Smith, A. (2006). Ethically Concerned, yet Unethically Behaved: Towards an Updated Understanding of Consumers' (Un)ethical Decision Making. Advances in Consumer Research, 33, 693-698. ISSN: 0098-9258.

Crane, A., Matten, D. (2004). Business Ethics, Oxford: OUP. 
Dahl, D. W., Honea, H, Manchanda, R.V. (2003). The Nature of Self-Reported Guilt in Consumption Contexts. Marketing Letters, 14(3), 159-171. doi: 10.1023/A:1027492516677

Dedeoglu, A. O., Kazancoglu, I. (2012). Consumer Guilt: A model of Its Antecedents and Consequences. Ege Academic Review, 12(1), 9-22. Retrieved from: http://www.onlinedergi.com/makaledosyalari/51/pdf2012_1_2.pdf

DePelsmacker, P, Janssens, W. (2007). A Model for Fair Trade Buying Behaviour: The Role of Perceived Quantity and Quality of Information and of Product-Specific Attitudes. Journal of Business Ethics, 75(4), 361-380. doi: 10.1007/s10551-006-9259-2

Dickson, M. (1999). US consumers' knowledge and concern with apparel sweatshops. Journal of Fashion Marketing and Management, 3(1), 44-55. doi:10.1108/eb022547

Eisenberg, N. (2000). Emotion, regulation, and moral development. Annual Review of Psychology, 51, 665697. Retrieved from: http://psych.colorado.edu/ tito/sp03/7536/eisenberg_2000.pdf http://dx.doi.org/10.1146/annurev.psych.51.1.665

Follows, S. B., Jobber, D. (2000). Environmentally responsible purchase behaviour: a test of a consumer model. European Journal of Marketing, 34(5/6), 723-747. doi: 10.1108/03090560010322009

François-Lecompte, A. (2005). La CSR: proposition et validation d'un cadre conceptuel intégrateur, Doctoral dissertation, University Pierre-Mendès-France, Grenoble.

Francois-Lecompte, A., Roberts, J.A. (2006). Developing a measure of socially responsible consumption in France. Marketing Management Journal, 16(2), 50-66.

Fritzsche, D. J. (1995). Personal values: Potential keys to ethical decision making. Journal of Business Ethics, 14 (11), 909-922. doi: 10.1007/BF00882069

Gabriel, Y., Lang, T. (1995). The Unmanageable Consumer. Sage, London.

Hassay, D. N, Smith, M. C. (1996). Compulsive Buying: An Examination of the Consumption Motive. Psychology and Marketing, 13(8), 741-752. doi:10.1002/(SICI)1520-6793(199612)13:8<741::AIDMAR2>3.0.CO;2-F

Holbrook, M. B., Hirschman, E. C. (1982). The Experiential Aspects of Consumption: Consumer Fantasies, Feelings, and Fun. Journal of Consumer Research, 9(2), 132-140. doi: 10.1086/208906

Hunt, Sh. D., Vitell, S. (1986). A General Theory of Marketing Ethics. Journal of Macromarketing, 6(1), 516. doi:10.1177/027614678600600103

Joergens, C. (2006). Ethical Fashion: Myth or future trend? Journal of Fashion Marketing and Management, 10(3), 1361-2026. doi:10.1108/13612020610679321

Kivetz, R., Simonson, I. (2002). Self-Control for the Righteous: Toward a Theory of Precommitment to Indulgence. Journal of Consumer Research, 29(2), 199-217. doi:10.1086/341571

Marks, L. J., Mayo, M. A. (1991). An Empyrical Test of a Model of Consumer Ethical Delimmas. Advances in Consumer Research, 18(1), 720-728. Retrieved from: http://www.acrwebsite.org/search/viewconference-proceedings. aspx $? \mathrm{Id}=7242$

Miao, L. (2011). Guilty Pleasure or Pleasurable Guilt? Affective Experience of Impulse Buying in HedonicDriven Consumption. Journal of Hospitality and Tourism Research, 35(1), 79-101. doi: 10.1177/1096348010384876

Millan, E. S., Howard, E. (2007). Shopping for pleasure? Shopping experiences of Hungarian consumers. International Journal of Retail \& Distribution Management, 35(6), 474-487. doi: $10.1108 / 09590550710750340$

Millar, M. G., Tesser, A. (1986). Effects of Affective and Cognitive Focus on the Attitude- Behavior Relationship. Journal of Personality and Social Psychology, 51(2), 270-276. doi:10.1037/00223514.51.2.270

Mohr, L. A., Webb, D. J., Harris, K. E. (2001). Do Consumers Expect Companies to be Socially Responsible? The Impact of Corporate Social Responsibility on Buying Behavior. Journal of Consumer Affairs, 35(1), 45-72. doi:10.1111/j.1745-6606.2001.tb00102.x

Nicholls, A., Lee, N. (2006). Purchase Decision-Making in Fair Trade and the Ethical Purchase 'Gap': Is there a Fair Trade 'Twix'? Journal of Strategic Marketing, 14(4), 369-386. doi:10.1016/j.cam.2005.08.035

Nicholls, A., Opal, C. (2005). Fair Trade: Market-Driven Ethical Consumption. Sage, London. 
Paek, H. J., Nelson, M. R. (2009). To Buy or Not to Buy: Determinants of Socially Responsible Consumer Behavior and Consumer Reactions to Cause-Related and Boycotting Ads. Journal of Current Issues and Research in Advertising, 31(2), 75-90. doi:10.1080/10641734.2009.10505267

Rintamaki, T., Kanto, A., Kuusela, H., Spence, M T. (2006). Decomposing the value of department store shopping into utilitarian, hedonic and social dimensions: evidence from Finland. International Journal of Retail \& Distribution Management, 34(1), 6-24. doi: 10.1108/09590550610642792

Roberts, J. A. (1995). Profiling levels of socially responsible consumer behavior: A cluster analytic approach and its implications for marketing. Journal of Marketing Theory and Practice, 3(4), 97-114. Retrieved from: http://www.jstor.org/stable/40469779

Roberts, J. A. (1996). Green consumers in the 1990s: Profile and implications for advertising. Journal of Business Research, 36(3), 217-231. doi:10.1016/0148-2963(95)00150-6

Roberts, J.A. (1996). Will the real socially responsible consumer please step forward? Business Horizons, 39(1), 79-83. doi:10.1016/S0007-6813(96)90087-7

Seiders, K. B., Berry, L. L., Gresham, L. G. (2000). Attention, retailers! How convenient is your convenience strategy? Sloan Management Review, 41(3), 79-89. ISSN: 0019-848X.

Shaw, D. S., Clarke, I. (1998). Culture, Consumption and Choice: Towards a Conceptual Relationship. Journal of Consumer Studies and Home Economics, 22(3), 163-168. doi:10.1111/j.14706431.1998.tb00727.x

Sidgwick, H. (1981) The Methods of Ethics (Seventh Edition). Foreword by John Rawls. Hackett Publishing Company, Indianapolis.

Smith, N. C. (1990). Morality and the Market: Consumer Pressure for Corporate Accountability. Routledge, London.

Soper, K. (2007). Rethinking the 'good life'. Journal of Consumer Culture, 7(2), 205-229. doi: $10.1177 / 1469540507077681$

Soper, K. (2008). 'Alternative Hedonism' and the Citizen Consumer. In Soper, K.and Trentmann, F. (ed), Citizens and Consumption. Palgrave Macmillan, Hampshire.

Soper, K., Ryle, M. \& Lyn, T. (2009). The Pleasures and Politics of Consuming Differently: Better Than Shopping. Palgrave Macmillan, London.

Strahilevitz, M., Myers, J. G. (1998). Donations to Charity as Purchase Incentives: How Well They Work May Depend on What You Are Trying to Sell. Journal of Consumer Research, 24(4), 434-446. Retrieved from: http://citeseerx.ist.psu.edu/viewdoc/download?doi=10.1.1.335.5883\&rep=rep1\&type=pdf

Szmigin, I., Carrigan, M. (2006). Exploring the Dimensions of Ethical Consumption. European Advances in Consumer Research, Vol. 7, 608-613. Retrieved from: http://www.acrwebsite.org/volumes/eacr/vol7/europeanvolume7_25.pdf

Tangney, J.P., Dearing, R. Shame and Guilt (2002). Guilford, New York.

Teller, C., Reutterer, T., Schnedlitz, P. (2008). Hedonic and Utilitarian Shopper Types in Evolved and Created Retail Agglomerations. The International Review of Retail, Distribution and Consumer Research, 18 (3), 283-309. doi: 10.1080/09593960802113877

Tsakiridou, E., Boutsouki, C., Zotos, Y. \& Mattas, K. (2008). Attitudes and Behaviour Towards Organic Products: an Exploratory Study. International Journal of Retail and Distribution Management, 36(2), 158-175. doi: 10.1108/09590550810853093

Turley, L. W., Milliman, R. E (2000). Atmospheric effects on shopping behavior: a review of the experimental evidence. Journal of Business Research, 49(2), 193-211. doi: 10.1016/S01482963(99)00010-7

Vitell, S. J., Singhapakdi, A., Thomas, J. (2001). Consumer Ethics: An Application and Empirical Testing of the Hunt-Vitell Theory of Ethics. Journal of Consumer Marketing, 18(2), 153-178. doi:10.1108/07363760110386018

Webster, F. E. Jr. (1975). Determining the characteristics of the socially conscious consumer. Journal of Consumer Research, 2(3), 188-196. doi:10.1086/208631

Wertenbroch, K. (2002). Hedonic Interactions between Choice and Consumption. Advances in Consumer Research, 29(1), 105-107. Retrieved from: http://www.acrwebsite.org/search/view-conferenceproceedings.aspx? $\mathrm{Id}=8570$ 